\title{
Mycobacterium hassiacum: a thermophilic Mycobacterium species to demonstrate thermal disinfection of medical devices
}

\author{
Bruno Haas ${ }^{*}$, Kelly J. Soto ${ }^{2}$, Dana S. Day ${ }^{2}$, Alexander C. Roy ${ }^{2}$, Marie-Claude Gagnon ${ }^{1}$, Jodi R. Alt ${ }^{2}$ \\ and Philippe Labrie ${ }^{1}$
}

\begin{abstract}
Objective: Reprocessing reusable medical devices is crucial in the healthcare industry. To ensure patient safety, strict standards are dictated to validate thermal disinfection in automated washer-disinfectors. The United States Food and Drug Administration (FDA) has specific recommendations on the vegetative bacterial challenge but comparatively vague guidance on the use of a thermophilic Mycobacterium strain for thermal disinfection studies. This study aims to compare thermal resistance of Mycobacterium hassiacum and Mycobacterium terrae and determine which strain is suitable for medical device thermal disinfection validation testing in automated washer-disinfectors.
\end{abstract}

Results: Thermal resistance was demonstrated in vitro by calculating D-values for each strain at different exposure temperatures, and correlated with actual in situ processing conditions. M. terrae was completely killed (> 7 log reduction) at temperatures above $68{ }^{\circ} \mathrm{C}$, with $\mathrm{D}$-values between 46.6 and $27.8 \mathrm{~s}$ at temperatures between 59.5 and $67.2^{\circ} \mathrm{C}$. M. hassiacum was completely killed (> 8 log reduction) at temperatures above $75^{\circ} \mathrm{C}$, with D-values between 82.1 and $21.7 \mathrm{~s}$ at temperatures ranging between 69.2 and $73.6^{\circ} \mathrm{C}$. In vitro results were correlated in a washer-disinfector performance validation setup.

Keywords: Medical devices, Thermal disinfection, Mycobacterium

\section{Introduction}

Thousands of reusable medical devices are processed daily at healthcare facilities in order to be re-used on patients. Specially designed washer-disinfectors clean and disinfect reusable medical devices at high throughput following strict standards and guidelines applicable to the field $[1,2]$. To ensure patient safety, semi-critical medical devices should ideally be sterilized, or at minimum must be subjected to high-level disinfection [3, 4]. According to the United States Food and Drug Administration (FDA) guidance, thermal disinfection must be

\footnotetext{
*Correspondence: Bruno_Haas@steris.com

1 STERIS Canada ULC, 490, Boulevard Armand-Paris, Quebec City, QC G1C 8A3, Canada
}

Full list of author information is available at the end of the article demonstrated by a $6-\log _{10}$ reduction of a mixed population of vegetative bacterial strains such as Pseudomonas aeruginosa, Staphylococcus aureus, Escherichia coli, and a representative of the Klebsiella/Enterobacteria group (low-level disinfection). In addition, 3- to $6-\log _{10}$ reduction of a thermophilic Mycobacterium species must also be achieved for intermediate- and high-level disinfection, respectively [2].

The validation of automated washing and disinfection of reusable medical devices has greatly contributed to the reduction of clinical infections [5]. Chemical disinfection and thermal disinfection are two different processes. Two parameters must be considered to evaluate thermal disinfection: time and temperature of exposure. As per chemical disinfection, the choice of the model organisms is crucial in order to keep a high safety margin. In the late 90 s, debates 
in standards committees raised the need for a surrogate strain representative of Mycobacterium tuberculosis and Mycobacterium avium-intracellulare to safely assess mycobactericidal activity in chemical disinfection of medical devices. In 1998, Griffiths et al. suggested the use of Mycobacterium terrae since it possesses similar resistance profile towards disinfectants compared to that of M. tuberculosis and M. avium-intracellulare [6]. However, there are no recommended Mycobacterium strains to validate thermal disinfection. The only guidance, from the U.S. FDA, is to use a thermophilic strain [2].

The International Organization for Strandardization's standard series ISO 15883 addresses thermal disinfection levels using the $\mathrm{A}_{0}$ concept that represents a time-temperature correlation of a thermal treatment [7]. It is the equivalent time in seconds at $80^{\circ} \mathrm{C}$ delivered by the disinfection process with reference to a microorganism with a $z$ value of $10 \mathrm{~K}[8,9]$. In 2016, McCormick et al. detailed the $\mathrm{A}_{0}$ concept and described Mycobacterium terrae as a model for thermophilic Mycobacterium species [10]. However, no evidence of $M$. terrae thermophilic properties is available. The only reference to $M$. terrae susceptibility to thermal treatment was described in 2011 by Pisot et al. [11]. They found a complete inactivation of $M$. terrae at $65{ }^{\circ} \mathrm{C}$. This behaviour does not correspond with the definition of "thermophilic" [12].

In 1997, Schröder et al. discovered a new Mycobacterium species named Mycobacterium hassiacum [13]. M. hassiacum is characterized as thermophilic as it can show optimal growth at temperatures up to $65^{\circ} \mathrm{C}$ [14]. When compared to $M$. terrae, $M$. hassiacum could present substantial benefits when used in a thermal disinfection validation setup. First, it meets the FDA guidance that a thermophilic strain of Mycobacterium should be used in thermal disinfection studies. Second, M. hassiacum is a fast-growing species; colonies can generally be obtained within 8 days of incubation at $37^{\circ} \mathrm{C}$ whereas $M$. terrae is a slow-growing species, with colonies appearing after 14 to 21 days of incubation at $37^{\circ} \mathrm{C}$. Finally, M. hassiacum can be easily identified as the test organism, since it has specific phenotypic characteristics including colony shapes and a distinctive yellow color.

In the present study, the thermal resistance of both $M$. terrae and M. hassiacum was determined by $\mathrm{D}$-value calculation. The resulting $\mathrm{D}$-values were compared in order to determine which strain could be most suitable as a bacterial challenge in thermal disinfection performance validation of medical washer-disinfectors.

\section{Main text \\ Methods}

\section{In vitro testing}

Bacterial seed culture preparation Mycobacterium hassiacum DSM 44199 (Deutsche Sammlung von Mikroor- ganismen und Zellkulturen, DSMZ, Germany) (equivalent to American Type Culture Collection [ATCC] 700660) [15] and Mycobacterium terrae ATCC 15755 (Microbiologics, USA) were grown on Middlebrook 7H11 agar containing $10 \%$ oleic acid, dextrose, catalase enrichment (OADC) and incubated at $37^{\circ} \mathrm{C}$ for 7 days (M. hassiacum) or 14 days (M. terrae).

Thermal resistance testing Three independent $M$. hassiacum and M. terrae suspensions (at least $10^{7}$ Colony Forming Units per milliliter [CFU $/ \mathrm{ml}]$ in $0.85 \%$ saline $+0.1 \%$ Tween 80) were exposed to thermal treatments of various times and temperatures in a heated water bath. Fractional growth data were used to calculate $\mathrm{D}$-values for each Mycobacterium species. A temperature check tube was used to monitor the temperature during treatments. The samples were diluted in peptone water and plated on 7H11 agar supplemented with 10\% OADC and incubated at $37^{\circ} \mathrm{C}$ for 7 days (M. hassiacum) or 14 days (M. terrae). Following incubation, CFU were counted to determine bacterial survival using the following formula:

$$
\mathrm{T}=\log _{10}(\mathrm{~N} * \mathrm{D})
$$

where, $\mathrm{T}=$ bacterial titer; $\mathrm{N}=$ average number of $\mathrm{CFU}$ at the valid dilution; $\mathrm{D}=$ dilution factor of the valid dilution.

$D$-value calculation The $\mathrm{D}$-value is the time required, at a given temperature, to decrease the bacterial population by $1 \log _{10}$.

Treatment temperatures were determined by calculating the average temperature recorded during the treatment time. For each temperature, the average bacterial count $\left(\log _{10}\right)$ was plotted on a graph (Y axis: $\log _{10}$ bacterial count; $\mathrm{X}$ axis: time of treatment). The $\mathrm{D}$-value for each temperature was calculated using the following formula:

$$
\mathrm{D}=-1 / \text { slope }
$$

\section{Tests in washer-disinfector}

Bacterial culture and test ampoules Mycobacterium hassiacum ATCC 700660 (Cedarlane, Canada) (equivalent to DSM 44199) [15] was grown at $37^{\circ} \mathrm{C}$ in Middlebrook $7 \mathrm{H} 9$ broth with glycerol for 7 days. The resulting culture was directly used as test suspension.

Mycobacterium terrae ATCC 15755 (Innovation Diagnostics Inc., Canada) was suspended in $0.85 \%$ Saline $+0.1 \%$ Tween 80 to an optical density at $620 \mathrm{~nm}$ wavelength $\left(\mathrm{OD}_{620}\right)$ of 0.1 (bacterial titer estimated $>10^{7} \mathrm{CFU} / \mathrm{ml}$ ).

$1.4 \mathrm{ml}$ of test suspensions of $M$. terrae and M. hassiacum (at least $10^{7} \mathrm{CFU} / \mathrm{ml}$ ) were sealed in glass ampoules 
and used to test bacterial thermal resistance during a mock thermal phase in a washer disinfector.

Washer-disinfector test setup A single-chamber washer disinfector was connected to a preheated water reservoir. Water at the desired temperature was passed through the washer's chamber for $1 \mathrm{~min}$ on a simulated medical instrument load with ampoules placed at the coldest area as determined per thermal profiling (data not shown). The following five treatment temperatures were tested for a 1-min contact time: $65{ }^{\circ} \mathrm{C}, 70{ }^{\circ} \mathrm{C}, 75^{\circ} \mathrm{C}, 80{ }^{\circ} \mathrm{C}$, and $85^{\circ} \mathrm{C}$. Ampoules of M. hassiacum and M. terrae were processed at the same time and thus received identical treatments. Once the 1-min water circulation was achieved, the ampoules were placed in ice cold water to immediately stop the heat treatment. The entire content of each ampoule was plated to assess bacterial survival by counting CFUs following 7-days incubation (M. hassiacum) or 14-days incubation (M. terrae) at $37^{\circ} \mathrm{C}$. The initial titer of each test suspension was also determined to represent the positive control (untreated ampoules).

\section{Results}

\section{In vitro testing}

The results of the in vitro thermal treatments including bacterial survival and D-values (in seconds) are shown in Fig. 1.

M. terrae Treatments for $M$. terrae were performed at temperatures between 59.5 and $67.2{ }^{\circ} \mathrm{C}$ since temperatures higher than $68{ }^{\circ} \mathrm{C}$ resulted in complete kill for most of the exposure times tested (data not shown). For all treatment temperatures, bacterial survival of $M$. terrae decreased as treatment time increased (Fig. 1, upper panel). D-values obtained for $M$. terrae ranged between 27.8 and 46.6 s. For replicate 1, D-values of 41.1, 38.1, 32.6, and $34.7 \mathrm{~s}$ were obtained for treatments at 59.5, 61.0, 66.0, and $66.2^{\circ} \mathrm{C}$, respectively. Replicate 2 resulted in D-values of $32.2,27.8$, and $29.6 \mathrm{~s}$ with treatments at $63.7,64.4$, and $65.5{ }^{\circ} \mathrm{C}$, respectively. D-values obtained on replicate 3 were $46.6,34.4,34.6$, and $27.8 \mathrm{~s}$ for treatments at 63.2, $64.8,64.9$, and $67.2^{\circ} \mathrm{C}$, respectively.

M. hassiacum Treatments on M. hassiacum suspensions were performed at temperatures between 69.2 and $73.6^{\circ} \mathrm{C}$. Bacterial survival decreased when treatment temperature or time increased (Fig. 1, lower panel). D-values obtained for replicate one were $80.5,40.7$, and $21.7 \mathrm{~s}$ for treatments at $69.2,71.5$, and $73.6{ }^{\circ} \mathrm{C}$, respectively. On replicate two, treatments at $69.6,71.4$, and $72.7^{\circ} \mathrm{C}$ led to D-values of 82.1, 53.2, and $34.2 \mathrm{~s}$, respectively. The third replicate resulted in D-values of $66.3,75.3$, and $37.0 \mathrm{~s}$ at 69.3, 71.2, and $73.3^{\circ} \mathrm{C}$.
Comparison of the highest treatment temperatures for $M$. terrae and the lowest treatment temperatures for $M$. hassiacum, showed that at $67.2{ }^{\circ} \mathrm{C}, 1-\log _{10}$ reduction of M. terrae was achieved after $27.8 \mathrm{~s}$ whereas at $69.2{ }^{\circ} \mathrm{C}$, $1-\log _{10}$ reduction of $M$. hassiacum was achieved after $80.5 \mathrm{~s}$.

\section{Washer-disinfector testing}

When tested in sealed glass ampoules in a washer-disinfector, it was found that $M$. terrae survival was significantly affected following a 1-min treatment at $65^{\circ} \mathrm{C}(3.6$ $\log _{10}$ reduction from $7.4 \log _{10} \mathrm{CFU} / \mathrm{ml}$ to $3.8 \pm 1.6 \log _{10}$ $\mathrm{CFU} / \mathrm{ml}$ ) (Fig. 2). When treatment temperature was increased to $70{ }^{\circ} \mathrm{C}$ and above, no surviving $\mathrm{CFU}$ were recovered from any ampoules tested for $M$. terrae.

In contrast, no significant reduction of bacterial survival was observed for $M$. hassiacum when treated at $65{ }^{\circ} \mathrm{C}$ for $1 \mathrm{~min}$. When temperature was raised to 70 and $75^{\circ} \mathrm{C}$, a 1 -min treatment lead to 0.2 and $0.6 \log _{10}$ reduction of the initial titer, respectively. However, the reduction was not significant. When treated for $1 \mathrm{~min}$ at 80 and $85^{\circ} \mathrm{C}$, a complete kill of $M$. hassiacum was observed.

\section{Discussion}

Mycobacterium terrae has been the surrogate of choice to safely test tuberculocidal activity of chemical disinfectants in the healthcare industry [6]. Another reliable way to disinfect thermo-resistant medical devices is to use an automated washer-disinfector that can perform thermal disinfection. International standard ISO 15883-2 evaluates thermal disinfection in terms of $\mathrm{A}_{0}$ values $[8,10,16]$. In addition, bacterial thermal resistance can be expressed using the calculated D-values which represent the time needed to decrease a bacterial population of $1 \log _{10}$ at a given temperature [17].

In vitro testing showed that survival of $M$. terrae was affected beginning at temperature treatments of $60{ }^{\circ} \mathrm{C}$ and higher. $M$. hassiacum survival was not affected by treatment temperatures below $68{ }^{\circ} \mathrm{C}$ (data not shown). $\log _{10}$ reduction of both $M$. terrae and $M$. hassiacum were time and temperature dependent. However, the two strains were not affected at the same temperature ranges. $M$. terrae depicted a complete kill when submitted to treatments at temperatures higher than $68{ }^{\circ} \mathrm{C}$, which is in accordance with previous observations [11]. Results obtained when testing $M$. terrae in a washer disinfector were in concordance with in vitro data, i.e. a complete kill at temperatures above $68^{\circ} \mathrm{C}$.

For critical medical devices such as surgical instruments, the ISO 15883 standard series recommends an $\mathrm{A}_{0}$ of 600 for disinfection $[1,7]$. This is equivalent to a 1-minute $(60 \mathrm{~s})$ treatment at $90{ }^{\circ} \mathrm{C}$. The present study demonstrates that an $\mathrm{A}_{0}$ of $60\left(1 \mathrm{~min}\right.$ at $\left.80^{\circ} \mathrm{C}\right)$ is enough to kill 


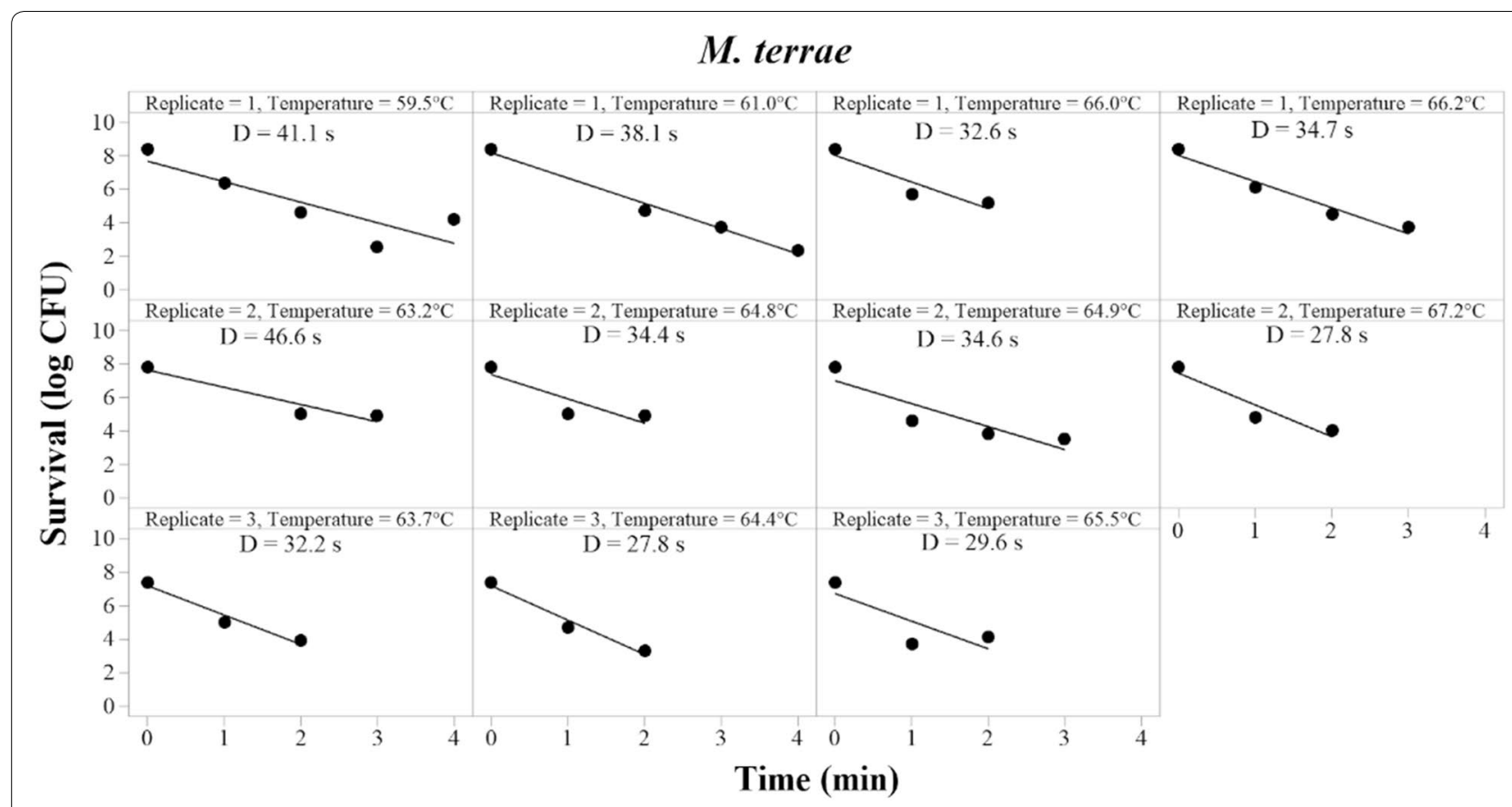

\section{M. hassiacum}

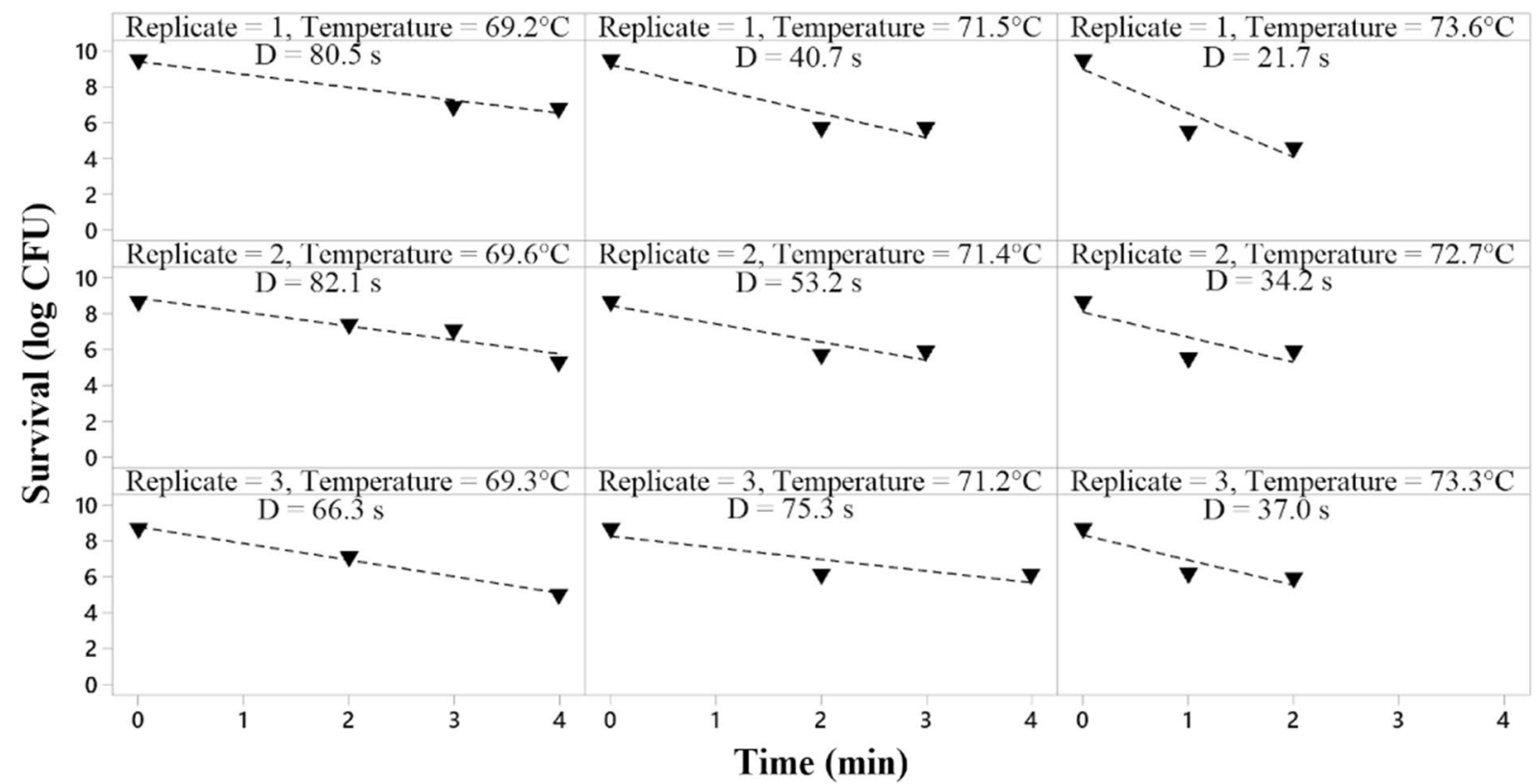

Fig. 1 M. terrae (upper panel) and M. hassiacum (lower panel) survival and calculated D-values as function of treatment time and temperature in vitro

7 to $8 \log _{10}$ of $M$. terrae or M. hassiacum in a laboratory setup. A sufficient safety margin has to be considered for field application; the $A_{0} 600$ is therefore reasonable to ensure high-level disinfection of critical devices. More importantly, the data collected during this study demonstrate that $M$. hassiacum is more suitable than $M$. terrae as a test organism to validate the tuberculocidal effect of thermal disinfection in an automated washer-disinfector.

To our knowledge, $M$. terrae thermal resistance has never been studied in detail [11], and there is no evidence of its thermophilic behaviour that justifies its use for thermal disinfection validation tests. M. hassiacum 


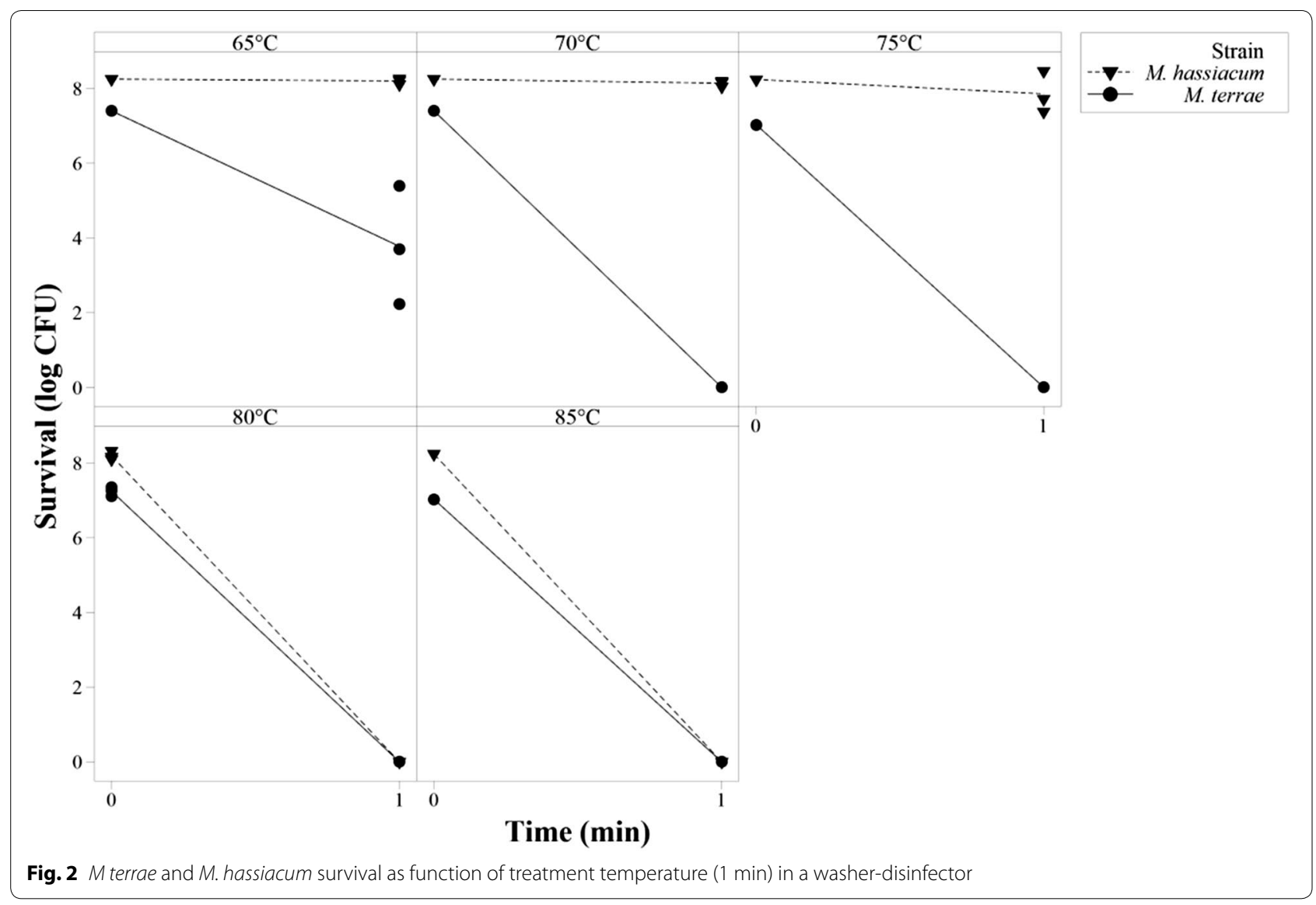

is a strain that was described for its thermophilic properties [13, 15], and showed in the present study a higher resistance to thermal treatment than $M$. terrae. Therefore, we recommend the use of $M$. hassiacum as the thermophilic Mycobacterium species surrogate of choice to validate thermal disinfection in automated washerdisinfectors. The choice of model organisms is crucial to keeping a high safety margin to ensure patient safety when reprocessing medical devices in automated washer-disinfectors.

\section{Limitations}

Variability was observed between replicates. Aggregation of the bacteria could have been causing variable results. Mycobacteria are known to aggregate due to their hydrophobicity thus causing difficulties obtaining homogeneous single-cell suspensions.

\section{Abbreviations}

U.S. FDA/FDA: United States Food and Drug Administration; ISO: International Organization for Standardization; DSMZ: Deutsche Sammlung von Mikroorganismen und Zellkulturen; ATCC: American Type Culture Collection; OADC: Oleic acid, dextrose, catalase enrichment; CFU: Colonies forming units; $\mathrm{OD}_{620}$ : Optical density at $620 \mathrm{~nm}$ wavelength.

\section{Acknowledgements \\ Not applicable.}

\section{Authors' contributions}

BH designed the study. KJS, DSD and ACR performed the in vitro testing while BH and MCG performed the washer-disinfector tests. PL and JRA supervized the study and represented the study's sponsor, STERIS Corporation. BH analyzed the data, KJS audited the analysis. All authors contributed to drafting and reviewing the resulting paper. All authors read and approved the final manuscript.

\section{Funding}

All aspects of the study (design, data collection, analysis and interpretation, and manuscript writing) were funded by STERIS Corporation.

\section{Availability of data and materials}

Not applicable.

Ethics approval and consent to participate

Not applicable.

\section{Consent for publication}

Not applicable.

\section{Competing interests}

All authors are employed by STERIS Corporation, a company that manufactures medical washer-disinfectors. STERIS Corporation funded the study.

\section{Author details}

1 STERIS Canada ULC, 490, Boulevard Armand-Paris, Quebec City, QC G1C 8A3, Canada. ${ }^{2}$ STERIS Corporation, Mentor, OH, USA. 
Received: 29 January 2020 Accepted: 25 February 2020

Published online: 10 March 2020

\section{References}

1. ISO 15883-1:2006(E) Washer-disinfectors-Part 1: general requirements, terms and definitions and tests, 2006.

2. FDA: Class II special controls guidance document: medical washers and medical washer-disinfectors; guidance for the Medical Device Industry and FDA Review Staff. 2002.

3. Spaulding EH. Chemical disinfection and antisepsis in the hospital. J Hosp Res. 1957:9:5-31.

4. Rutala WA, Weber DJ, and the Healthcare Infection Control Practices Advisory Committee (HIPAC). 2019. Guideline for disinfection and sterilization in healthcare facilities, 2008. https://www.cdc.gov/infectioncontrol/pdf/ guidelines/disinfection-guidelines-H.pdf.

5. Bergo Mdo C. Evaluation of cleaning and disinfection performance of automatic washer disinfectors machines in programs presenting different cycle times and temperatures. Rev Lat Am Enfermagem. 2006;14:735-41.

6. Griffiths PA, Babb JR, Fraise AP. Mycobacterium terrae: a potential surrogate for Mycobacterium tuberculosis in a standard disinfectant test. J Hosp Infect. 1998;38:183-92.

7. ISO 15883-2:2006(E) Washer-disinfectors_-Part 2: requirements and tests for washer-disinfectors employing thermal disinfection for surgical instruments, anaesthetic equipment, bowls, dishes, receivers, utensils, glassware, etc. 2006.

8. Rosenberg U. Thermal disinfection - the $\mathrm{A}_{0}$ concept and the biological background. ZentrSteril. 2003;11:118-20.

9. Uetera Y, Kawamura K, Kobayashi H, Saito Y, Yasuhara H, Saito R. Studies on viral disinfection: an evaluation of moist heat disinfection for HBV by using $A_{0}$ concept defined in ISO 15883-washer-disinfectors. PDA J Pharm Sci Technol. 2010;64:327-36.
10. McCormick PJ, Schoene MJ, Dehmler MA, McDonnell G. Moist heat disinfection and revisiting the A0 concept. Biomed Instrum Technol. 2016;50(Suppl 3):19-26.

11. Pisot S, Thumm G, Heeg P, Syldatk C, Roth K. Investigations into the role of the $A_{0}$ value in the inactivation kinetics of bacteria in thermal disinfection. ZentrSteril. 2011;10:37-41.

12. Brock TD. Thermophilic microorganisms and life at high temperatures. Springer Series in Microbiology. New York: Springer; 1978. https://doi. org/10.1007/978-1-4612-6284-8.

13. Schroder KH, Naumann L, Kroppenstedt RM, Reischl U. Mycobacterium hassiacum sp. nov., a new rapidly growing thermophilic mycobacterium. Int J Syst Bacteriol. 1997;47:86-91.

14. Tiago I, Maranha A, Mendes V, Alarico S, Moynihan PJ, Clarke AJ, MacedoRibeiro S, Pereira PJ, Empadinhas N. Genome sequence of Mycobacterium hassiacum DSM 44199, a rare source of heat-stable mycobacterial proteins. J Bacteriol. 2012;194:7010-1.

15. Tortoli E, Reischl U, Besozzi G, Emler S. Characterization of an isolate belonging to the newly described species Mycobacterium hassiacum. Diagn Microbiol Infect Dis. 1998;30:193-6.

16. Rohm-Rodowald E, Jakimiak B, Chojecka A, Wiercinska O, Ziemba $B$, Kanclerski K. Recommendations for thermal disinfection based on the $\mathrm{A}_{0}$ concept according to EN ISO 15883. Przegl Epidemiol. 2013;67(687-690):769.

17. Bigelow WD, Esty JR. The thermal death point in relation to time of typical thermophilic organisms. J Infect Dis. 1920;27:602-17.

\section{Publisher's Note}

Springer Nature remains neutral with regard to jurisdictional claims in published maps and institutional affiliations.
Ready to submit your research? Choose BMC and benefit from:

- fast, convenient online submission

- thorough peer review by experienced researchers in your field

- rapid publication on acceptance

- support for research data, including large and complex data types

- gold Open Access which fosters wider collaboration and increased citations

- maximum visibility for your research: over $100 \mathrm{M}$ website views per year

At BMC, research is always in progress.

Learn more biomedcentral.com/submissions 